\title{
BRYOPHYTES ÖF ALTAI MOUNTAINS. I. STUDY AREA AND HISTORY OF ITS BRYOLOGICAL EXPLORATION.
}

\author{
MOХООБРАЗНЫЕ АЛТАЯ. I. \\ РАЙОН ИССЛЕДОВАНИЯ И ИСТОРИЯ ЕГО БРИОЛОГИЧЕСКОГО ИЗУЧЕНИЯ
}

\author{
MICHAEL S. IGNATOV ${ }^{1}$ \\ M. С. ИГНАТOB ${ }^{1}$
}

\begin{abstract}
In the introductory paper of the series the study area of Russian Altai is defined. Comments on its physiography and bryophyte composition of the main types of vegetation are provided. History of the bryological exploration of Altai is discussed. Preliminary list of Altaian mosses is given, with the altitudinal range and frequency for each species.

Резюме

Начиная с этого выпуска Arctoa предполагает опубликовать серию статей, в которых будут описаны и иллюстрированы мохообразные Алтая. Во вступительной части приведены сведения об истории изучения мохообразных Алтая, его природных условиях, растительном покрове и комплексах мохообразных основных типов растительности. Дан также предварительный список мхов Алтая (480 видов, 10 разновидностей), с указанием диапазона высот и частоты встречаемости для каждого вида.
\end{abstract}

\section{INTRODUCTION}

Starting with this issue of Arctoa I am putting forward a series of papers on bryophytes of Altai Mountains. In recent years a lots of specimens were collected in this region, including manyspecies new to the area or poorly known in the world. Also, critical studies of previously collected materials reveal many novelties. Although a conspectus of the moss flora of Altai and Sayan Mountains has been published relatively recently by L. V. Bardunov (1974), the knowledge can now be sufficiently supplemented. Furthermore, the series will provide most of the species with description, illustration, and discussion on their distinguishing features, and in some cases, also on their nomenclature and systematic position.

\section{STUDY AREA}

There are at least two definitions of the Altai Mountain Range. In the maps of U.S. National Geographic Society (for example, National Geographic 181(6): 70A, 1992) and in many Atlases, this name is applied to a mountain sys- tem starting from the Russian Altai on the north-west, through the Chinese and Mongolian Altai, to Gobi Altai. Under such approach, Altai extends to about two and a half thousand kilometers, representing a huge and very heterogeneous territory. Another definition, which is commonly used in the Russian-language literature and also in some European editions, for example in Encyclopaedia Britannica (1902, v. 25), defines Altai to mean only the part situated within the Russia, while the other parts are named differently as Chinese Altai, Mongolian Altai, and Gobi Altai. This latter concept is accepted here (Fig. 1). Accordingly, Altai area includes the territory of (1) Republic Altai (as Gorno-Altaiskaya Autonomic Republic and Oirotskaya Oblast in earlier periods), formerly a part of Altaiskiy Territory, but became separated from the latter since 1991, and (2) the neighboring part of Altaiskiy Territory. Not included in the present consideration is the western slope of Altai in the Kazakh Republic. Delimited in such a way, the study area is about 


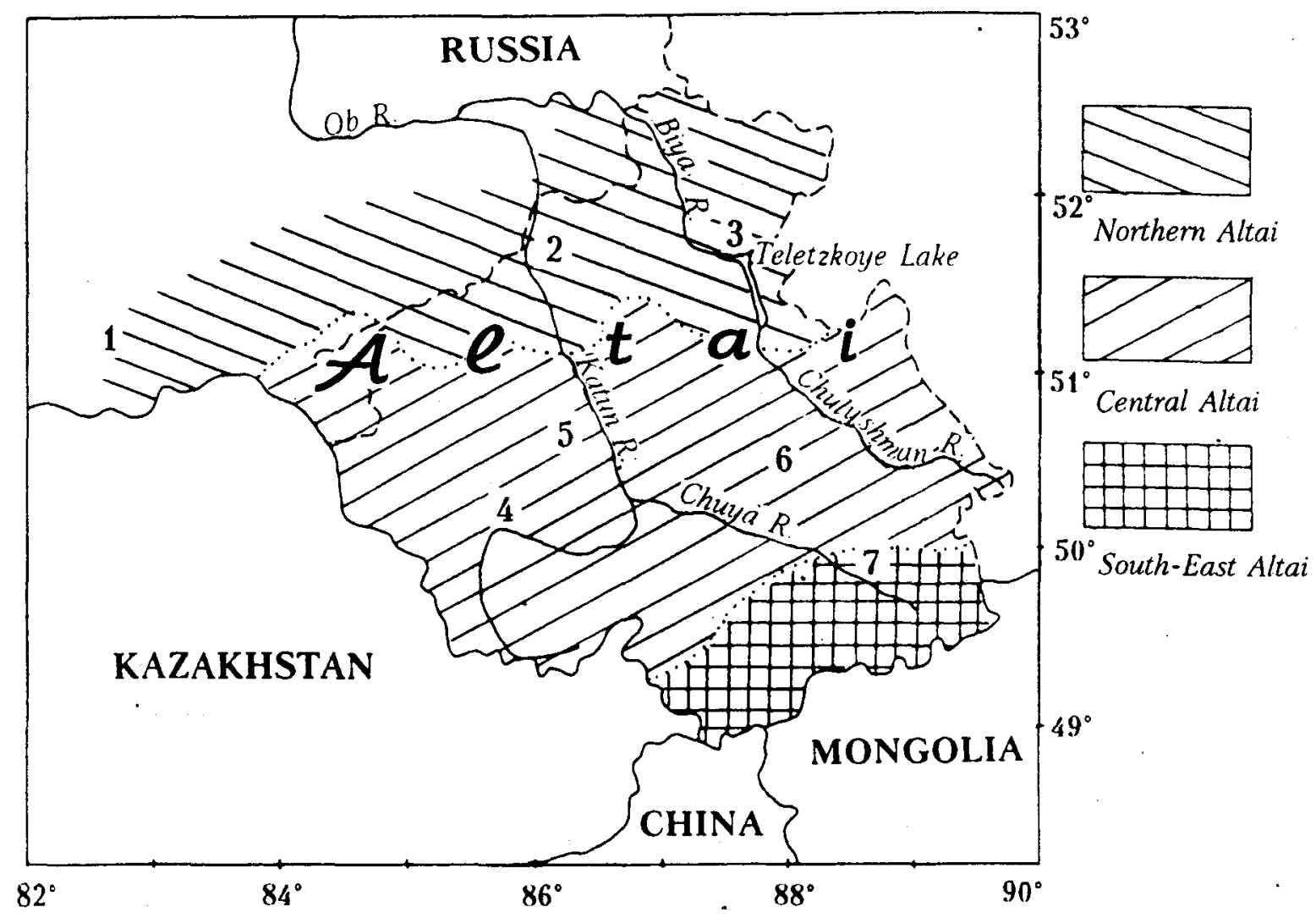

Fig. 1. Map of Altai, as it defined for present study, with bryogeographic subdivisions; numbers show places for which climatic diagrams are given on Fig. 2.
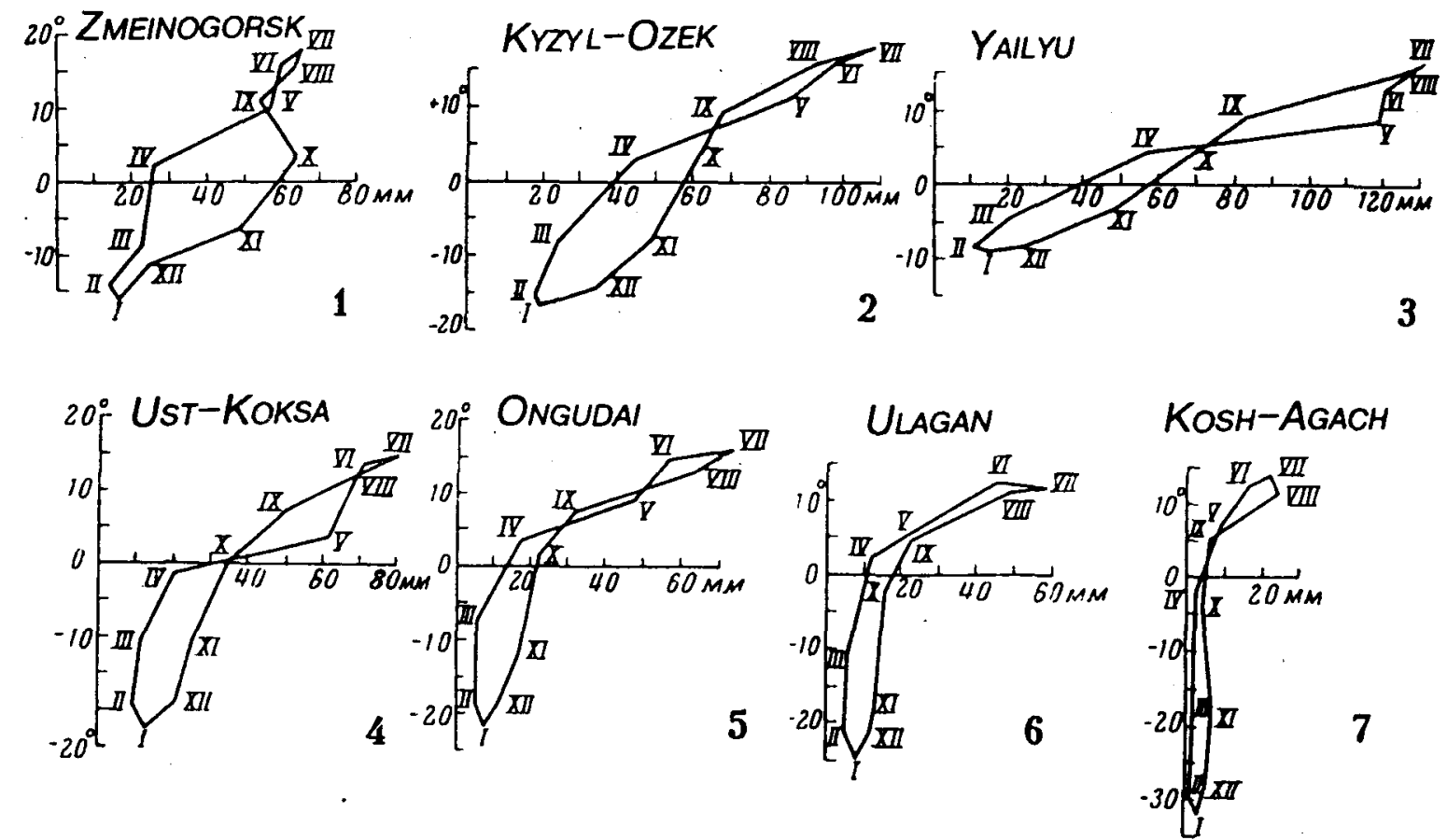

Fig. 2. Climatic diagrams (monthly temperature and precipitation) of Altai, the numbers correspond those on Fig. 1 (after Kuminova, 1960). 
120000 square kilometers, with an altitudinal range from ca. $250 \mathrm{~m}$ to $4506 \mathrm{~m}$ of the Belukha Peak. About $1.5 \%$ of territory is above $3000 \mathrm{~m}$, ca. $23 \%$ - at $2000-3000 \mathrm{~m}, 50 \%$ - at 1000 $2000 \mathrm{~m}, 25 \%$ - below $1000 \mathrm{~m}$. Because of the presence of late and permanent snow-fields and glaciers, only a limited number of collections were made above $3000 \mathrm{~m}$.

\section{Climate}

Diversity of climatic conditions of Altai is great. Average annual temperatures range from +4 to $-8^{\circ} \mathrm{C}$, and colder in high mountains. The western slope, which is the main acceptor of humidity of Atlantic air masses, receives to about $1600 \mathrm{~mm}$ of annual precipitation. The inner or southeast slopes of Altai, however, receive only $124 \mathrm{~mm}$ in Kosh-Agach and Chuiskaya Steppe.The subalpine zone at about tree line receives the maximum precipitation about twothree times more than that at middle elevations (Krivonosov, 1975). Some data of local climate are given as diagrams in Fig. 2.

\section{VegETATION}

The vegetation types are described by Kuminova (1960) and Ogureeva (1980). They are classified into semi-desert, steppe, forest-steppe, forest, subalpine and alpine/tundra types. But within each of these, there are a number of contrasting variations corresponding to vegetational provinces. (l.c.):

Four main provinces are recognized by Ogureeva

(1) Western Altai - characterized by well-precipitated steppes and occurring mostly outside the study area in the Kazakh Altai. This province is peculiar in its steppe composition and is probably not so for bryophytes. Moreover, the province is rather poorly explored for bryophytes;

(2) Northern or North-Eastern Altai - a humid area without steppes, but with widespread Abies sibirica Ledeb. and Pinus sibirica De Tour forests of a rather wet type, called also czernevaya taiga. Such forests, as showed by Bardunov (1974) and Gudoshnikov (1986), exhibit a species composition that is temperate rather than boreal. There is no continuous moss carpet on forest ground where tall grasses or ferns often dominate. Because of milder and wetter climate, this area is especially rich in bryophytes and many species are known in the Altai region only from here, especially from the surroundings of Teletzkoye Lake;

(3) Central Altai - occupying most of the territory of Altai. This province comprises a mosaic of fragments of steppe, forest-steppe, forests (both wet Abies + Pinus sibirica czernevaya taiga, and boreal forest, or northern taiga dominated by Pinus sylvestris L., P. sibirica, Picea obovata Ledeb., Larix sibirica Ledeb.), and various types of subalpine and alpine vegetations; northern part of this region is more humid and classified in special subregion;

(4) South-Eastern Altai which is most unique in having semi-desert (very fragmentary inside Russian territory) and a very widespread cool steppe vegetation. The latter, in many cases, gradually changes into tundra vegetation with fragmentary Larix forests (rarely with Picea obovata and Pinus sibirica). General physiogeography of South-Eastern Altai is closer to that seen in Mongolia Republic. In many subdivisions of Altai this part has a higher rank such that the first subdivision of Altai would be SouthEastern Altai and the rest of Altai.

The available bryological data allow the subdivision of Altai also into three regions, corresponding somewhat to the above described regions.

(1) Northern Altai (including also Western Altai and northern part of Central Altai, in definitions of Ogureeva and Kuminova) is distinctive in having a positive specificity of species such as Eurhynchium hians, E. angustirete, Hylocomiastrum umbratum, Heterophyllium affine, Podperaea krylovii, Buxbaumia minakatae, Thamnobryum neckemides, Dicranella heteromalla, Orthothecium intricatum, and Ulota hutchinsiae, etc. There is a great abundancy of temperate groups like Ulota, Orthotrichum, Neckera, Homalia, Atrichum, Myuraclada, etc., which, however, are known also from Central Altai, at least in its northern part. The transition of this region into Central Altai is gradual. In some deep canyons and wet places in Central Altai, the moss flora is fairly reminiscent that of the North-Eastern Altai;

(2) Central Altai has mostly a negative "peculiarity" (absence of species of North-East and SouthEast). Its positive specificity includes only a few rather rare species, Ptychomitrium sinense, Grimmia pilifera, Physcomitrella patens, Onthotrichum pumilum;

(3) With respect to bryophytes, South-Eastern Altai is delimited much more sharply from the rest than one would expect. Only here are found genera such as Indusiella, Voitia, Phascum, Crossidium, and species such as Pterygoneurum ovatum, Plagiobryum demissum, Pseudocalliergon turgescens, Hennediella heimii, Tortula leucostoma, Syntrichia caninerois. Very abundant here are Tayloria froelichiana, T. acuminata, Stegonia spp., and Ctenidium procerrimum, which are rare in other parts of Altai. Striking here is the absence of common species of Central Altai like Samentypnum sarmentosum, Racomitrium lanuginosum, $R$. microcarpon, Polytrichum piliferum. There is no species of Sphagnum found here, although $50 \mathrm{~km}$ away they are numerous and abundant. The wet habitats are dominated by Aulacomnium palustre, sometimes 
with $A$. turgidum and Tomentypnum nitens. Inside Larix forests are found Hylocomium splendens and Rhytidium rugosum, while Pleurozium schreberi is totally absent(!), although not rare $50 \mathrm{~km}$ apart in the taiga habitat. Many unusual combinations of species were observed in South-Eastern Altai.

\section{VERTICAL ZONATION}

Vertical zonation of forests of Northern and Central Altai is principally similar. At lower elevations, below $1000-1400 \mathrm{~m}$, the forests are composed of conifers, sometimes with considerable addition of Betula $a l b a \mathrm{~L}$. and Populus tremula L. Two main complexes can be segregated: the more humid type represented by Pinus sibirica + Abies sibirica forests, usually with Picea obovata; and the more xeric type of Pinus sylvestris + Betula alba or B. pendula Roth, and also Larix sibirica. These two forest types differ considerably in their vascular plant composition, but their bryophyte components are more or less homogeneous. This is because bryophytes occur mostly on rock outcrops, ravines, slopes, canyons, brook banks, wet depressions and other habitats having a specific microclimate of their own. There is no constant species association present on soil in these forest types. Among the more or less frequent taxa are Atrichum flavisetum, Eurhynchium hians, Rhytidiadelphus triquetrus, Pleurozium schreberi. Typically on tree trunks are Brachythecium reflexum, B. salebrosum, Amblystegium serpens, Hypnum pallescens, Entodon cladorrhizans, Plagiomnium cuspidatum, Plagiothecium laetum, Dicranum scoparium, Pohlia nutans, Frullania paroistipula, Ptilidium pulcherrimum, Pylaisiella polyantha, P. selweynii, Orthotrichum speciosum, $O$. sordidum, Orthodicranum spp., etc., most of which occur also on rotten logs. In drier areas and on fallen logs are Orthodicranum flagellare, Oncophorus wahlenbergii, Platygyrium repens, Hypnum fertile, Bryohaplocladium microphyllum. Under more humid condition, epiphytes, including Neckera pennata, Orthotrichum spp. Ulota spp., and Homalia trichomanoides, become more numerous and abundant. On rotten logs here are continuous carpets of Dicranodontium denudatum, Tetraphis pellucida, Bazzania bidentula, Lophozia incisa and Tritomaria exsecta. On mesic rocks at these elevations are characteristically Anomodon attenuatus, A. viticulosus, Leucodon sciuroides, Brachythecium populeum, $B$. buchananii, Tortula sinensis, Eurohypnum leptothallum, Hypnum cupressiforme, Plagiomnium confertidens, Trachycystis ussuriensis, Hedwigia ciliata, Schistidium strictum, Apometzgeria pubescens, Porella platyphylla, Frullania dazurica, etc. Also abundant are common species like Hylocomium splendens, Abietinella abietina, Pleurozium schreberi, Rhytidium rugosum, Ptilidium crista-castrensis. Wet cliffs are rich in rather rare species: Bartramia pomiformis, Blindia acuta, Cirriphyllum cirrosum, Cyrtomnium hymenophylloides, Ditri- chum flexicaule, Encalypta procera, Fissidens adianthoides, Hypnum hamulosum, H. callichroum, Isopterygiopsis muellerana, Mnium homum, M. thomsonii, Myurella sibirica, Orthothecium chryseum, Plagiobryum zieri, Plagiomnium rostratum, Plagiopus oederiana, Polytrichum pallidisetum, Thamnobryum neckeroides, Timmia noroegica, Brachythecium plumosum, Hymenostylium recurvirostrum, etc.

The forest-steppes and steppes which occupy the more xeric regions of Central Altai are poor in bryophytes. The more widespread species here are Rhytidium rugosum, Abietinella abietina, Tortula nuralis (these three are common practically in all the types of vegetation in Altai, including the high-alpine zone), and sometimes also Entodon concinnus, Trachycystis ussuriensis, and Hypnum vaucheri. Together, they form a somewhat pure blanket of ground moss in shrubby land consisting of Caragana, Berberis, Rhododendron, and on pasture land. Here on rocks are typically found Orthotrichum anomalum, Grimmia ovalis, G. tergestina, Bryum argenteum, Tortula sinensis, and in more xeric regions, Jaffueliobryum latifolium is very abundant.

From elevations of $1000-1400 \mathrm{~m}$ to the tree line, the conifer forests of boreal type, or taiga, appear. Though the tree composition of taiga is practically the same as that in the forests below, their structures are strikingly different. Herbs are rare but ericaceous shrublets are common in taiga. Mosses usually form continuous carpets which consist mostly of Hylocomium splendens, often with Pleurozium schreberi, Rhytidiadelphus triquetrus, $R$. subpinnatus, Sphagnum capillifolium, etc. Epiphytes are rare and Dicranum fragilifolium, D. fuscescens, Plagiothecium laetum, Isopterygiopsis pulchella, Lophozia incisa, L. incisa, Tritomaria exsectiformis, Bleparostoma trichophyllum, Lepidozia reptans are typically seen on rotten logs. Constantly present on rocks are Ulota curoifolia and Cynodontium strumiferum.

The tree line in Altai varies from 1800 in NW to $2400 \mathrm{~m}$ in SE. It is formed in most parts of Central and Northern Altai by Pinus sibirica stands. This subalpine zone combines fragments of taiga and open areas occupied mostly by shrubs of Betula rotundifolia Spach (Betula nana L. p. p.) that are of $0.5-1.5 \mathrm{~m}$ high. Under such shrubs, called also "yernik", in bogs in wetter places are abundant species of Sphagnum, Aulacomnium palustre, Tomentypnum nitens, Wamstorfia exannulata and Campylium stellatum. Dominants on drier sites under Betula shrubs are Polytrichastrum alpinum, Rhytidium rugosum, Dicranum flexicaule ( $D$. congestum auct.) and lichens of the genera Cladonia, Cladina, Stereocaulon and Cetraria. As mentioned earlier, this zone is the most humid typically with precipitation everyday. It is very rich in bryophytes; here are recorded 290 species, nearly as much as in lower forest zone, where 299 species were recorded. Many alpine species are found here (Grimmia 
incuroa, G. donniana, G. funalis, Aulacomnium turgidum, Kiaeria starkei), and some alpine species restricted to this belt (Pohlia crudoides, Psilopilum laevigatum, Hygrohypnum alpestre, Schistidium agassizii, Campylopus schimperi, $C$. fragilis etc.). Some temperate forest species that are typically absent in taiga are found to penetrate occasionally into the zone of tree line. Examples are Anomodon attenuatus, Leucodon sciudoides, Struckia argentata ssp. zerovii, Myuroclada maximowiczii, Atrichum flavisetum, etc. Other species known only or predominantly from the subalpine zone are Cnestrum alpestre, Cynodontium tenellum, Splachnum sphaericum, and the single endemic genus of Altai and the neighbouring Western Sayan Mts., Orthodontopsis bardunovii. Recently descibed from one Altaian and one Sayanan localities, it is now known from 12 localities where it occurs on rotten logs within a narrow range of about $200 \mathrm{~m}$ of elevations between subalpine open stands and upper taiga zone. In the belt of about tree line there are very widespread also different kinds of bogs, so many Sphagnum species are known only from here (i.e. $S$. lindbergii, $S$. jensenii, $S$. riparium, etc.).

Tall herb vegetation (Aconitum, Delphinium, Angelica, Heracleum, Paeonia, etc.) sometimes is developed in upper taiga and subalpine zone. The vascular plant covers are usually too dense and dark at ground level to favor any moss growth. However, in some places are seen the common Rhytidiadelphus triquetrus, $R$. subpinnatus, Dicranum majus, Brachythecium erythrorrhizon, Scleropodium ormellanum, Plagiochila porelloides, and Barbilophozia spp. This assemblage of bryophytes occurs also underneath the herbaceus cover of yernik (with Geranium, Doronicum, etc).

The lower part of alpine zone is covered also with shrubs of Betula rotundifolia (sometimes intermixed with Salix glauca L., S. krylovii E. Wolf, and other willows), forming especially dense growth up to 2000$2500 \mathrm{~m}$. Finally, in the upper alpine zone there are representatives of a variety of lichen and rocky tundras. Bryophytes frequently growing on soil in the alpine zone are Dicranum spadiceum, D.congestum, Paraleucobryum eneroe, Polytrichum piliferum, Polytrichastrum alpinum, Aulacomnium palustre, A. turgidum, and on rocks or lithosoil are $G$. affinis, $G$. donniana, $G$. elatior, $G$. funalis, $G$. incurva, Racomitrium microcarpon, $R$. canescens, Orthotrichum laevigatum var. japonicum, O. rupestre, Pohlia filum, Andreaea nupestris, A. alpestris, Ceratodon purpureus, Distichium capillaceum, Saelania glaucescens, etc. Common along streams are Hygrohypnum polare and Sarmentypnum sarmentosum. Extensive Sphagnum bogs are not seen in this zone, and mosses such as Meesia uliginosa, Paludella squarrosa, Limprichtia revolvens, L. cossonii, Stramigeron stramineum (=Calliergon stramineum), Sphagnum spp., Brachythecium turgidum occur mostly in hummocks along streams or lake shores, or in springy bogs on mountain slopes.

South-Eastern Altai has an altitudinal range from ca. 1400 to $3500 \mathrm{~m}$. Vegetations at the bottom of river valleys are semi-deserts or steppes. In most areas there is a severe disturbance caused by over-grazing of the local vegetation. Larix forests occupy mostly the steep slopes of northern aspect. They mostly have no continuous moss carpet or it is formed mainly of Rhytidium rugosum. Steppe vegetation in many places transforms directly into tundra.

\section{GEOLOGY}

Altai Mountains were formed in Late Paleozoic and had the most considerable recent uplift in Middle Oligocene-Miocene (Bogachkin, 1981).

Most of the rocks in Altai are of early Paleozoic age. They are either of magmatic origin or of marine deposits. Despite considerable differences in their chemical composition, various rocks are so strongly metamorphosed that they looks very similar. The most common type of rocks in Altai is the grayish-green chlorite-sericite schist which is difficult to classify as acidic or basic because of its complex composition and the numerous varieties of more or less basic types. Calcareous outcrops are not very common, but calcareous argillites or limestones are known here and there in relatively restricted areas. The latter typically are hard in texture, close to mramor. Acidic rocks such as granites, are very widespread, especially in high mountain areas. Sandstones are uncommon. Moraine deposits, often chemically strongly calcareous, are common in many regions.

\section{HistORY OF VEGETATION}

In the Paleogene on the territory of South Siberia and Kazakhstan broad leaved forests with thermophilous conifers, Taxodium, Sequoia and Metasequoia, were widespread (Dorofeev, 1964; Malyshev \& Peshkova, 1984; Zhilin, 1991). However already in Oligocene the percent of Picea in pollen spectra was considerable (Bogachkin, 1981). Toward the Pliocene, forest composition became more and more boreal with the predominance of Pinus (especially $P$. sibirica), Abies, Picea, Tsuga, although the presence of broad-leaved trees (Carpinus, Tilia, Corylus, Ulmus) remained apparent up to the end of early Pleistocene (ca. 600000 BP). A later important event is the xerophytization of vegetation and formation of steppe zone in Late Miocene and Pliocene. These changes were due to, probably, not only the planetary cooling, but also the great changes in continental Asiatic air circulation pattern. As discussed by Chang (1983), the Neogene-Quaternary uplift of Tibetan Plateau blocked the Central Asia from the wet and warm southern air currents from 
Indian Ocean. This uplift resulted also in the formation of Tibetan and Siberian-Mongolian Anti-cyclones. And as a consequence, xeric territories developed in Central Asia, including the Mongolia and Inner Altai.

The Late Pleistocene cooling, about 45-35 thousand years BP, resulted in glaciation of about $35 \%$ of Altai territory (now glaciers occupy about $1 \%$ ), and the snow line was at $1600-2100 \mathrm{~m}$ alt., or about 800 $900 \mathrm{~m}$ lower than the present day position. In the valleys glaciers penetrated down to $1200-1000 \mathrm{~m}$ (Okishev, 1982). However, according pollen spectra, even in the most severe periods forests of Pinus sibirica and Picea survived even in close proximity to glaciers (Boyarskaya, 1978). All the present vegetational zones, probably existed during the time of maximal glaciation with just some vertical shifts, so Tertiaty temperate relicts seems had a chance to survive.

Another probable time period when the temperate flora could reach the Altai is during the Holocene climatic maximum (6000-5000 years BP). As restored by Klimanov (1989) on the basis of correlation of numerous pollen spectra throughout Eurasia, the temperature and precipitation in Altaian region and its surroundings were higher at the time. According to Belov \& Belova (1986), Tilia, Quercus and Ulmus occurred in the surrounding of Baikal Lake where the same genera are absent today, being present remotely by $1-2$ thousand $\mathrm{km}$.

After this short optimum period, a progressive cooling process followed throughout the Holarctic. The relatively warmer and cooler periods probably alternated many times. A better documented period is the last cooling, so called the Minor Glacial Period. It started in about XIV century and had a definite climatic minumum in 1780-1850. The occurrence of a cooling period was proven by an analysis of moraine deposits and cross sectional study of Larix trunks (Adamenko, 1985; Okishev, 1982). According to Okishev, mean annual temperature before this period was $0.3^{\circ} \mathrm{C}$ higher than present, and during the period the temperature dropped $0.9^{\circ} \mathrm{C}$. Thus, the main Altaian glaciers had their lower ends reaching $70 \mathrm{~m}$ below the present line. In term of vegetation, the more cool-resistant Larix forests were much more widespread in the Altai. Today no juvenile Larix is seen in many old Larix stands, where young trees of Picea obovata and Pinus sibirica became abundant. Only in South-East Altai is the survival of Larix forests still visible. So, one can conclude that the climate of South-East Altai (see Fig. 2) was characteristic for much wider area just two centures ago.

\section{BRYOLOGICAL EXPLORATION}

The first collections from Altai were made by Petr Shangin in 1786 (specimens at LE). However, they were identified much later, so that in Shangin's publications no bryophytes were mentioned. Such situation continued well into the XIX and the early XX century with the collections of I. Politov - 1837, F. Gebler - 1837, V. V. Sapozhnokov - 1890s, I. V. Vereshchagin - 1903-1909 \& 1919, P. N. Krylov 1903, N. I. Kusnezov -1913 and other collectors who did not mention bryophytes in their travel accounts. In spite of, these collections accumulated in several herbaria in St.-Petersburg, Tomsk and Helsinki.

The first publication on Altaian bryophytes is, probably, the list produced by A. Zass (1894) which included mostly vascular plants and 6 bryophytes without exact localities.

The first more or less comprehensive list of bryophytes of Altai appeared in the report of expedition of B. A. Keller (1914). This report contains numerous releves which include vascular plants, bryophytes and lichens, and, in addition, detailed geographical and pedological information. A list of 92 bryophytes which was presented in a special index fully referred to the releves was rich in ecological information for every species. The collection base of this report was made mostly by P. I. Kurskij (Kursky) in 1909, M. P. Tomin in 1910, and by Keller himself. All collections were identified by V. F. Brotherus and are at $\mathrm{H}$.

Brotherus also received rich materials for identification from Krylov from the herbarium of Tomsk University. These include the Altaian collections of Krylov, Vereshchagin, Sapozhnikov, and to a lesser extend, those of A. I. Ivanizkaya and A. P. Vydrin. Later Krylov (1925) published the identifications of 217 species and 4 varieties in a list for the Altai area by current definition.

In 1914 Brotherus started to contribute his moss treatments to the "Flora Asiatskoj Rossii" (Flora of Asian Russia) which was edited by B. A. Fedtschenko. Three parts were published (Brotherus, 1914, 1918, 1931), covering acrocarpous species from Andreaeaceae to Encalyptaceae, in which Altaian materials were carefully cited.

B. S. Semenov $(1921,1922)$ published two booklets about the Sphagna and pleucarpous mosses of Altai, basing on his own collections and on the collections of Krylov determined by Brotherus. His publications contain keys, descriptions, illustrations and lists of localities, which are, however, less complete than the Krylov (1925) materials.

Since 1920s many geobotanists and floristicians of vascular plants collected bryophytes in Altai and deposited the specimens at LE after their identifications were made by L. I. Savicz-Ljubitskaya and A. L. Abramova. Among these are sufficient numbers of unusual and interesting collections made by V.I. Baranov, B. K. Schischkin, A. G. Krylov \& S. P. Rechan, T. Yu. Vozzhennikova, I. A. Palamarchuk, A.G. Kalinina, and many others. In their publications, these authors mentioned, however, only the widespread 
species used in the characterization of some vegetational types (Krylov \& Rechan, 1967; Ogureeva, 1980).

In 1934, soon after the organization of the Altaian State Reserve in Eastern Altai which covered ca. 8800 sq. $\mathrm{km}$., intensive investigations of bryophytes started. The collections of M. S. Khomutova, A. N. Goncharova, M. V. Zolotovskij and some others were identified by N. V. Samsel (Moscow) and published by Khomutova \& al. (1938) with full citation of the labels for 2 hepatics and 49 mosses. However, these specimens can not be located today.

Later M. Schmidt, Volkova and G. Kreps (1930s) collected bryophytes in Altaian State Reserve and deposited the specimens at LE and H. From 19401967, the Reserve was abolished. After its re-establishment in 1967, collecting activity resumed. Numerous specimens were collected by N. I. Zolotukhin - 1976-1993, I. N. Zolotukhina (Lebedeva), E. F. Koroleva, and many others. Collections were sent to me for identification and were preserved in MHA.

Additional various collections are deposited in herbaria such as MHA (coll. V.V.Makarov \& al. 1972), LB (D.K.Zerov - 1940; E.I.Vysozkaya - 1977), LWS (V.M.Melnichuk - 1953). From these collections only the more interesting species were published (Abramova \& Abramov, 1966; Lazarenko, 1946; Kulik, 1990; Kulik \& Ulychna, 1990; Ulychna, 1990).

Inspite of the long overview above, the first professional bryological investigation of Altai mosses was undertaken by L.V.Bardunov in 1966 . Working many years before in the neighboring Sayan Mountains, Bardunov was the first to collect mosses with full intent. Previous authors either could not recognize in the field what they are collecting or, like Zerov and Melnichuk, had a rather limited time for a comprehensive investigation of bryophytes. Consequently, the visits of Bardunov added more than 100 species to the Altain moss flora. In his conspectus are reported 350 species for the entire area. The conspectus contains a general or exact (for rare species) geographic distribution, altitudinal distribution, habitat preference, and also an essay on the vegetational, geographic and ecological analyses of Altaian mosses. As a whole, Bardunov (1974) provided an excellent synthesis for the bryophyte flora of Altai and Sayan Mts. His collections are mainly kept in IRK.

In 1980s S. V. Gudoshnikov worked in Northern Altai. His collections were published in a review of bryophytes of Abies forests in Southern Siberia (Gudoshnikov, 1986).

Thus far, no publication on the Altaian hepatic flora has been attempted.

My own studies of bryophytes of Altai started in 1988 when Zolotukhin brought to my disposal his collections made from the Altaian State Reserve and its surroundings. In 1989 and 1991-93, I also collected numerous specimens in the Altai, depositing them mainly in MHA. Some collections have already been discussed (Ignatov, 1990, 1991, 1992; Ignatov \& Kurbatova, 1990; Ignatov \& Tan, 1991; Tan \& al., 1991; Czernyadjeva \& Ignatov, 1991; Ignatov \& Zander, 1993). Nevertheless, numerous additions remain unreported. Therefore, I am organizing the new information of Altaian mosses in this series in Arctoa journal.

The goals of the series are to report the occurrence of bryophytes in the Altai, to describe them and supply with keys to species determination, and also to illustrate them. The taxonomy of a certain groups will be discussed.

The distribution data of the Altaian mosses are stored in a database at MHA which contains the label and locality information. All information can be obtained free upon request by Arctoa subscribers.

Specimen citation includes name of locality, altitude, either the collector number (meaning that collector is Ignatov and specimen is in MHA), or name of collector and date and host herbarium (if herbarium acronym is not indicated - specimen is in MHA) and if present the collection number also.

Understandably, this series may not be completed within a few years. I am adding here therefore a preliminary list of Altaian mosses, believing that it can be used to better understanding the environmental situation. Since this list has been extracted very recently from my database, corrections and additions are certainly expected during the preparation of treatment for the various groups. Synonyms are given for names different from that in "Check-list of mosses of the the former USSR" (Ignatov \& Afonina, 1992). All species names are supplemented with information on the altitudinal range and number of specimen studied.

\section{AKNOWLEDGEMENTS}

I am greatly indebted to Dr. B. C. Tan for help with the English and many useful advices and to Drs. L. V. Bardunov and S. G. Kazanovskij for loan and for duplicates of many critical collections from IRK. I am also very thankful to J. Vana for the help with identifications of hepatics. The project on moss flora of Altai was supported in part by the grant M97000 of the International Science Foundation. 
Preliminary list of MOSSES of the Altai

\section{SPHAGNACEAE}

\section{Sphagnum}

angustifolium (Russ. ex Russ.) C.Jens aongstroemii C.Hartm.

balticum (Russ.) Russ. ex C.Jens.

capillifolium (Ehrh.) Hedw.

centrale C.Jens. ex H.Arnell et C.Jens.

compactum DC.

contontum Schultz

fallax (Klinggr.) Klinggr.

fimbriatum Wils.

flexuosum Dozy et Molk

fuscum (Schimp.) Klinggr.

gingensohnii Russ.

jensenii H.Lindb.

lindbergii Schimp. ex Lindb.

magellanicum Brid.

palustre L.

platyphyllum (Lindb. ex Braithw.)

Sull. ex Warnst.

quinquefarium (Lindb. ex Braithw.)

Warnst.

riparium Aongstr.

nubelhum Wils.

nussoreii Warnst.

squarrosum Crome

subsecundum Nees ex Sturm

teres (Schimp.) Aongstr. ex Hartm.

wamstorfii Russ.

\section{ANDREaEACEAE}

Andreaea

alpestris (Thed.) Schimp.

heinemannii Hampe et C.Muell.

obooata Thed.

rupestris Hedw.

- var. papillosa (Lindb.) Podp.

\section{Polytrichaceae}

Atrichum

flavisetum Mitt.

tenellum (Rohl.) B.S.G.

undulatum (Hedw.) P.Beauv.

Pogonatum

dentatum (Brid.) Brid.

umigenum (Hedw.) P.Beauv.

Polytrichastrum

alpinum (Hedw.) G.L.Sm.

Polytrichum

commune Hedw.

- var. jensenii (Hag.) Moenk.

- var. perigoniale (Michx.) Hampe

formosum Hedw.

juniperinum Hedw.

longisetum Sw. ex Brid.

- var. anomalum (Milde) Hag.

pallidisetum Funck

piliferum Hedw.

sexangulare Brid.

sp.n.

strictum Brid.
Psilopilum

laevigatum (Wahlenb.) Lindb.

19501

Buxbaumiaceae

Buxbaumia

minakatae Okam

4601

FISSIDENTACEAE

Fissidens

adianthoides Hedw.

bryoides Hedw.

osmundoides Hedw.

$340-880 \quad 10$

450-2550 22

450-2700 22

taxifolius Hedw.

500-600 5

2300-2350 3

450-2530 13

$1620-2300 \quad 18$

560-2350 18

1200-1950 7

20501

1200-2240 6 12001

1900-2500 9

560-600 2

$1950-2280 \quad 3$

2050-2400 5

1750-2280 9

440-1900 10

$520-21008$

$520-22806$

450-2500 27

DitrichaceaE

Ceratodon

purpureus (Hedw.) Brid.

- var. rotundifolius Berggr.

440-2800 40

23501

Distichium

capillaceum (Hedw.) B.S.G.

inclinatum (Hedw.) B.S.G.

Ditrichum

cylindricum (Hedw.) Grout

flexicaule (Schwaegr.) Hampe

heteromallum (Hedw.) Britt.

pallidum (Hedw.) Hampe

pusillum (Hedw.) Hampe

Saelania

glaucescens (Hedw.) Broth.

440-2800 44

$1750-27506$

400-1600 8

$340-2750 \quad 40$

4401

4401

450-520 2

450-2900 23

Seligeriaceae

Blindia

acuta (Hedw.) B.S.G.

470-2280 7

Seligeria

diversifolia Lindb.

pusilla (Hedw.) B.S.G.

23001

2050-2850 3

550-2908 32

1900-3150 7

recurvata (Hedw.) B.S.G.

440-1700 6

4001

6001

Dicranaceae

Brothera

leana (Sull.) C.Muell.

Campylopus

400-1900 19

fragilis (Brid.) B.S.G.

schimperi Milde

450-500 5

Cnestrum

alpestre (Wahlenb.) Nyh. ex Mogensen

schistii (Web. et Mohr) Hag

470-2850 17

450-3100 11

440-2908 30

440-2650 19

Cynodontium

fallax Limpr.

polycarpon (Hedw.) Schimp.

strumiferum (Hedw.) Lindb.

tenellum (B.S.G.) Limpr.

1600-2500 2

1650-2100 2

450-880 6

440-2908 25

470-2500 13

$1450 \quad 1$

470-880 5

400-2965 11

1800-2880 9

26001

Dichodontium

pellucidum (Hedw.) Schimp.

Dicranella

cerviculata (Hedw.) Schimp.

crispa (Hedw.) Schimp.

heteromalla (Hedw.) Schimp.

rufescens (Dicks.) Schimp.

schreberiana (Hedw.) Hilp.

ex Crum et Anderson

subulata (Hedw.) Schimp.

varia (Hedw.) Schimp.
450-550 8

$2250 \quad 1$

21002

19001

10001

450-1950 11

17601

440-2200 17

700-2400 23

340-1850 28

1950-2220 3

10001

480-1000 2

5001

280-1800 13

1000-2600 16
450-1700 10 
Dicranodontium

denudatum (Brid.) Britt

Dicranoweisia

crispula (Hedw.) Lindb.

intermedia Amman

Dicranum

acutifolium (Lindb. et H.Arnell)

C.Jens. ex Weinm.

angustum Lindb.

bergeri Bland. in Starke

bonjeanii De Not.

brevifolium (Lindb.) Lindb.

congestum Brid.

drummondii C.Muell.

elongatum Schleich. ex Schwaegr.

fragilifolium Lindb.

fuscescens Turn.

majus $\mathrm{Sm}$

muehlenbeckii B.S.G.

polysetum Sw.

scoparium Hedw.

spadiceum Zett.

Kiaeria

falcata (Hedw.) Hag.

starkei (Web. et Mohr) Hag.

Oncophorus

virens (Hedw.) Brid.

wahlenbergii Brid.

Orthodicranum

flagellare (Hedw.). Loeske

montanum (Hedw.) Loeske

Paraleucobryum

enerve (Thed.) Loeske

longifolium (Hedw.) Loeske

Rhabdoweisia

crispata (Dicks.) Lindb.

EnCALYptaceae

Bryobrittonia

longipes (Mitt.) Horton

Encalypta

alpina Sm.

brevicollis (B.S.G.) Bruch ex Aongstr.

ciliata Hedw.

procera Bruch

thaptocarpa Schwaegr.

oulgaris Hedw.

\author{
PottiaçeAE \\ Aloina \\ brezirostris (Hook. et Grev.) Kindb. \\ rigida (Hedw.) Limpr. \\ Barbula \\ amplexifolia (Mitt.) Jaeg: \\ conoohuta Hedw. \\ unguiculata Hedw. \\ Bryoerythrophyllum \\ alpigenum (Vent.) Chen \\ inaequalifolizm (Tayl.) Zander \\ recurvirostrum (Hedw.) Chen \\ Crossidium \\ squamiferum (Viv.) Jur. \\ Didymodon \\ asperifolius (Mitt.) Crum et al.
}

440-1850 25

$550-2650 \quad 33$

2300-2600 3

1760-2600 9

$2050-2530 \quad 3$

440-2400 17

$760-2500 \quad 20$

1920-2800 3

440-2600 43

18501

1760-2908 25

480-2000 25

450-2908 23

1920-2250 4

450-2300 6

450-2250 11

450-2650 15

1750-3010 49

19001

1900-2700 8

1750-2650 21

400-2400 35

440-1000 21

55-1800 17

1900-2800 16 .

440-2260 16

$380-2100 \quad 14$

440-1400 10

1900-2700 5

900-2300 12

$370-2400 \quad 46$

$350-2750 \quad 12$

340-2900 53

$1700-2400 \quad 4$

870-2700 9 440-2300 12

400-550 5

310-1800 15

450-900 7

450-2100 8

6001

$340-2750 \quad 49$

2200-2400 5

500-2800 5 cordatus Jur.

20001

fallax (Hedw.) Zander

400-800 6

icmadophilus (Schimp. ex C.Muell.) Saito 340-2700 34

johansenii (Williams) Crum

perobtusus Broth.

rigidulus Hedw.

vinealis (Brid.) Zander

$340-2400 \quad 11$

1100-2500 2

400-2400 22

450-2250 3

Eucladium

verticillatum (Brid.) B.S.G.

$350-3502$

Gymnostomum

aeruginosum $\mathrm{Sm}$.

calcareum Nees et Hornsch.

21001

6001

Hennediella

heimii (Hedw.) Zander (= Pottia heimii)

Hymenostylium

recurvirostrum (Hedw.) Dix.

Molendoa

schliephakei (Limpr.) Zander

(= Pleuroweisia schliephakei)

sendtneriana (B.S.G.) Limpr.

Phascum

cuspidatum Hedw.

Pterygoneurum

ovatum (Hedw.) Dix.

subsessile (Brid.) Jur.

Stegonia

latifolia (Schwaegr.)Vent. ex Broth.

pilifera (Brid.) Crum et Anderson

Syntrichia (= Tortula p.p.)

caninerois (Mitt.) Broth.

laevipila Brid.

noroegica Web.f.

pagorum (Milde) Amann

ruralis (Hedw.) Web. et Mohr

sinensis (C.Muell.) Ochyra

Timmiella

anomala (B.S.G.) Limpr.

Tortella

fragilis (Hook. et Wils.) Limpr.

inclinata (Hedw.f.) Limpr.

tortuosa (Hedw.) Limpr.

Tortula

cemua (Hueb.) Lindb.

(= Desmatodon cermuus)

euryphylla Zander

( $=$ Desmatodon latifolius)

laureri (Schultz) Lindb.

(= Desmatodon lauren)

leucostoma (R.Br.) Hook. et Grev.

(= Desmatodon leucostomus)

modica Zander (= Pottia intermedia)

mucronifolia Scbwaegr.

obtusifotia (Schwaegr.) Math.

(= Desmatodon obtusifolius)

systylia (Schimp.) Lindb.

(= Desmatodon systilius)

$1980-2150 \quad 4$

400-2750 21

2050-2450 4

24501

2150-2150 2

2150-2550 9

800-2200 5

1900-2800 13

2200-2700 4

1800-2500 11

1950-2350 6

1800-2900 5

1700-1800 2

440-2800 25

340-1700 38

$400-8008$

440-2750 34

2300-2700 2

$350-280030$

$1220-27506$

1950-2500 21

$2450 \quad 1$

2000-2500 7

18001

500-2500 23

440-550 2

$1800-27008$

Trichostomum

arcticum Kaal.

16501

crispulum Bruch in F.Muell.

teruirostre (Hook. et Tayl.) Lindb.

(= Oxystegus tenuirostris)

$340-20505$

350-1400 15

Tuerkheimia

soihlae (Bartr.) Zander 


\section{Weissia}

brachycarpa (Nees et Hornsch.) Jur. condensa (Voit) Lindb. controversa Hedw.

exserta (Broth.) Chen

\section{CinClidotaceaE \\ Cinclidotus \\ riparius (Brid.) Arnott}

\section{GRIMMIACEAE}

Coscinodon

cribrosus (Hedw.) Spruce

Grimmia

affinis Hoppe et Hornsch.

alpestris (Web. et Mohr)Schleich ex Nees 2000-2200 2 anodon B.S.G.

caespiticia (Brid.) Jur.

donniana $\mathrm{Sm}$.

elatior Bruch ex Bals. et De Not.

funalis (Schwaegr.) B.S.G.

incuroa Schwaegr.

laevigata (Brid.) Brid.

montana B.S.G.

ovalis (Hedw.) Lindb.

pilifera P.Beauv.

plagiopodia Hedw.

tergestina Tomm. ex B.S.G.

unicolor Hook.

Hydrogrimmia

moltis (B.S.G.) Loeske

Indusiella

thianschanica Broth. et C.Muell.

Jaffueliobryum

latifolium Lindb. et H.Arnell ex Ther.

Racomitrium

canescens (Hedw.) Brid.

lanuginosum (Hedw.) Brid.

microcarpon (Hedw.) Brid.

panschii (C.Muell.) Kindb.

sudeticum (Funck) B.S.G.

Schistidium

agassizii Sull. et Lesq.

apocarpum (Hedw.) B.S.G.

heloeticum (Schkuhr) Deguchi

bliputanum (C.Muell.) Deguchi

rioulare (Brid.) Podp.

strictum (Turn.) Maort.

\section{Funariaceae}

Funaria

hygrometrica Hedw.

muehlenbergii Turn.

Physcomitrella

patens (Hedw.) B.S.G.

SplachnaceaE

Splachnum

luteum Hedw.

rubrum Hedw.

sphaericum Hedw.

Tayloria

acuminata Hornsch.

froelichiana (Hedw.) Mitt. ex Broth.

lingulata (Dicks.) Lindb.

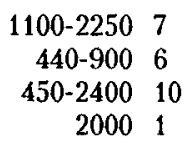

1100-2250 7

440-900 6

450-2400 10

20001

$340-400 \quad 4$

$2050-21002$

400-2966 118

$1600-2600 \quad 44$

1600-2400 13

$1930-315028$

400-2908 50

$1750-2750 \quad 36$

$1900-3151 \quad 42$

$340-1400 \quad 10$

$800-21002$

$340-2700 \quad 44$

450-2300 7

2200-2250 2

440-2300 20

$450-2700 \quad 18$

2400-2600 3

2100

$450-2500 \quad 15$

1920-3100 15

$880-2600 \quad 13$

$1665-3150 \quad 5$

$1860-2500 \quad 14$

1750-2050 5

400-2750 14

19501

1100-2100 6

440-2650 16

$400-2800 \quad 74$

450-2350 15 440-900 5

$450 \quad 1$

1250-2050 4

1660-2050 2

$1655-2400 \quad 4$

1400-2400 6

2300-2800 11

2100-2400 3
450-2890 13
Tetraplodon

angustatus (Hedw.) B.S.G.

1500-2100 8

mnioides (Hedw.) B.S.G.

urceolatus (Hedw.) Bruch et Schimp. 2070-2750 9

Voitia

nivalis Hornsch.

$2150-22003$

SchistostegaceaE

Schistostega

pennata Hedw.

$485-1900 \quad 4$

TETRAPHidacEaE

Tetraphis

pellucida Hedw.

Tetrodontium

brownianum (Dicks.) Schwaegr.

BRYACEAE

Anomobryum

julaceum (Gaertn. et al.) Schimp.

Bryum

algovicum Sendtn. ex C.Muell.

alpinum Huds. ex With.

argenteum Hedw.

caespiticium Hedw.

capillare Hedw.

creberrimum Tayl.

cryophilum Maort.

elegans Nees ex Brid.

funckii Schwaegr.

imbricatum (Schwaegr.) B.S.G.

neodamense Itzigs.

pallens (Brid.) Sw. ex Roehl.

pallescens Schleich. ex Schwaegr.

pseudotriquetrum (Hedw.) Gaertn. et al.

recuroulum Mitt.

schleicheri Schwaegr.

subelegans Kindb.

uliginosum (Brid.) B.S.G.

wameum (Roehl.) Bland ex Brid.

weigelii Spreng.

Leptobryum

pyriforme (Hedw.) Wils.

Orthodontopsis

bardunooii Ignatov et Tan

Plagiobryum

demissum (Hook.) Lindb.

zieri (Hedw.) Lindb.

Pohlia

andalusica (Hoehnel) Broth.

andrezesii Shaw

atropurpurea (Wahlenb. ex

Fuernr.) Lindb.

bulbifera (Warnst.) Warnst.

cruda (Hedw.) Lindb.

crudoides (Sull, et Lesq.) Broth.

drummondii (C.Muell.) Andrews

elongata Hedw

filum (Schimp.) Maort.

longicollis (Hedw.) Lindb.

melanodon (Brid.) Shaw

nutans (Hedw.) Lindb.

proligera (Kindb. ex Breidl.)

Lindb. ex H.Arnell

vexans (Limpr.) H.Lindb.
440-2250 16

470-2000 2

$350-280028$

2150-2550 2

900-2050 3

$440-2500 \quad 22$

440-2100 6

350-2500 11

$1900-2720 \quad 16$

440-1900 2

19501

1400-2300 2

$2350 \quad 1$

450-2300 3

$2500 \quad 1$

400-2750 29

9501

1665-2100 4

400-1000 6

2050-2400 3

$2800 \quad 1$

1665-2380

$400-2050 \quad 10$

$1600-2100 \quad 11$

$2450-2700 \quad 2$

440-2600 14

18001

440-3150 29

900-2300 4

$1760-25303$

440-3150 39

1930-2220 2

1800-2900 11

440-2800 34

1930-2850 10

$470-2700 \quad 22$

450-1800 5

$440-3150 \quad 36$

470-2150 4

1400-1760 2
450-2150 8 
wahlenbergii (Web. et Mohr) Andrews

Rhodobryum

ontariense (Kindb.) Kindb.

roseum (Hedw.) Limpr.

\section{MNIACEAE}

Cinclidium

stygium Sw

Cyrtomnium

hymenophylloides (Hueb.) Nyh. ex T.Kop. 440-2800 19

hymenophyllum (B.S.G.) Holmen

Mnium

homum Hedw.

marginatum (Dicks.) Beauv.

spinosum (Voit) Schwaegr.

spinulosum B.S.G.

stellare Hedw.

thomsonii Schimp.

Plagiomnium

acutum (Lindb.) T.Kop.

confertidens (Lindb. et H.Arnell) T.Kop.

cuspidatum (Hedw.) T.Kop.

drummondii (Bruch et Schimp.) T.Kop

ellipticum (Brid.) T.Kop.

medium (B.S.G.) T.Kop.

- ssp. curoatulum (B.S.G.) T.Kop.

rostratum (Schrad.) T.Kop.

Pseudobryum

cinclidioides (Hueb.) T.Kop.

Rhizomnium

andrewsianum (Steere) T.Kop.

magnifolium (Horik.) T.Kop.

pseudopunctatum (Bruch et Schimp.)

T.Kop

punctatum (Hedw.) T.Kop.

Trachycystis

ussuriensis (Maack et Regel) T.Kop.

Aulacomniaceae

Aulacomnium

palustre (Hedw.) Schwaegr.

turgidum (Wahlenb.) Schwaegr.

MeEsiaceae

Amblyodon

dealbatus (Hedw.) B.S.G.

Meesia

triquetra (Richter) Aongstr.

uliginosa Hedw.

Paludella

squarrosa (Hedw.) Brid.

\section{BARTRAMIACEAE}

Bartramia

ithyphylla Brid.

pomiformis Hedw.

Conostomum

tetragonum (Hedw.) Lindb.

Philonotis

fontana (Hedw.) Brid.

- var. caespitosa (Jur.) Schimp.

- var. pumila (Turn.) Brid.

- var. seriata (Mitt.) Kindb.

mollis (Dozy et Molk.) Mitt.

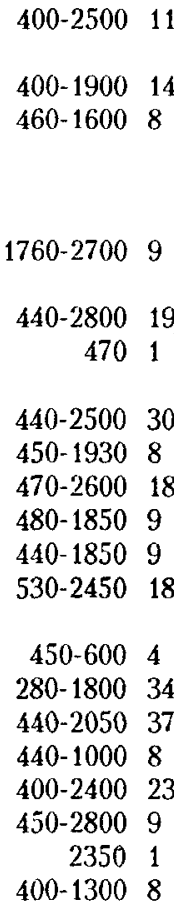

$1300-17503$

$2000-23502$

460-1400 11

$880-2400 \quad 16$

440-1400 12

$350-1100 \quad 38$

450-2800 21

$1150-285024$

$\begin{array}{rl}2300 & 1 \\ 2350-2700 & 3 \\ 1700-2800 & 19\end{array}$

$1000-2600 \quad 25$

1750-2908 20

400-1900 14

1930-2908 4

450-2400 12

$550-25003$

$1000-2800 \quad 31$

440-2300 2

400-450 2
Plagiopus

oederiana (Sw.) Crum et Anderson

440-2500 21

TimmiacEaE

Timmia

austriaca Hedw.

bavarica Hessl.

23001

$340-270020$

440-2800 12

Ptychomitriaceae

Ptychomitrium

sinense (Mitt.) Jaeg.

$420-450 \quad 6$

ORTHOTRICHACEAE

Amphidium

lapponicum (Hedw.) Schimp.

mougeotii (B.S.G.) Schimp.

Orthotrichum

alpestre Hornsch.

anomalum Hedw.

cupulatum Brid.

dasymitrium Lewinsky

laevigatum Zett.

- ssp. japonicum (Iwats.) Lewinsky

obtusifolium Brid.

pallens Bruch ex Brid.

pellucidum Lindb.

pumilum Sw.

rogeri Brid.

nupestre Schleich. ex Schwaegr.

sordidum Sull. et Lesq.

speciosum Nees

striatum Hedw.

- vladikaokanum Vent.

Ulota

crispa (Hedw.) Brid.

curoifolia (Wahlenb.) Lilj.

hutchinsiae (Sm.) Hammar

rehmannii Jur.

Zygodon

nupestris Lor.

(= Z. viridissimus var, nupestris)

$1900-23705$

$470-2400 \quad 8$

$1850-2300 \quad 8$

$310-2450 \quad 35$

24501

$\begin{array}{ll}750 & 1\end{array}$

$780-2780 \quad 19$

400-1100 14

550-2100 2

$1850-2750 \quad 3$

8001

4503

$880-2400 \quad 15$

440-1100 18

450-1600 28

440-470 9

440-11007

450-1000 24

1400-2250 10

4301

380-1000 12

4501

FontinaliaceaE

Dichelyma

falcatum (Hedw.) Myr.

Fontinalis

antipyretica Hedw.

hypmoides Hartm.

squamosa Hedw.

Climaciaceae

Climacium

dendroides (Hedw.) Web. et Mohr

HeDWIGIACEAE

Hedwigia

ciliata (Hedw.) Beauv.

LEUCODONTACEAE

Leucodon sciuroides (Hedw.) Schwaegr.

NeCKeRACEAE

Homalia

besseri Lob.

trichomanoides (Hedw.) B.S.G.
$440-2600 \quad 19$

$440-2750 \quad 34$

440-2100 29

1760-2700 5

400-1665 14

440-1900 5

? 1

440-550 2

400-1300 31 
Neckera

pennata Hedw.

\section{ThamnOBRYACEAE}

Thamnobryum neckeroides (Hook.) Lawt.

Theliaceae

Myurella

julacea (Schwaegr.) B.S.G. sibirica (C.Muell.) Reim. tenerrima (Brid.) Lindb.

\section{PterigYNANDRACEAE}

Pterigynandrum

filiforme Hedw.

\section{FABRONIACEAE}

Anacamptodon

latidens (Besch.) Broth.

Fabronia ciliaris (Brid.) Brid.

\section{Myriniaceae \\ Myrinia puloinata (Wahlenb.) Schimp.}

\section{LESKEACEAE}

Iwatsukiella leucotricha (Mitt.) Buck et Crum

Leptopterigynandrum austro-alpinum C.Muell.

Lescuraea saxicola (B.S.G.) Milde

Leskea polycarpa Hedw.

Leskeella neroosa (Brid.) Loeske

Pseudoleskea incuroata (Hedw.) Loeske radicosa (Mitt.) Kindb.

Pseudoleskeella catenulata (Brid. ex Schrad.) Kindb. papillosa (Lindb.) Kindb. tectomum (Funck ex Brid.) Kindb.

\section{ANOMODONTACEAE}

\section{Anomodon}

attenuatus (Hedw.) Hueb.

longifolius (Brid.) Hartm.

viticulosus (Hedw.) Hook. et Tayl.

\section{THUIDIACEAE}

Abietinella

abietina (Hedw.) Fleisch.

- var. hystricosa (Mitt.) Sak.

Bryohaplocladium angustifolium (Hampe et C.Muell.) Wat. et Iwats.

microphylhum (Hedw.) Wat. et Iwats.

Claopodium pellucineroe (Mitt.) Besch.

Heterocladium dimorphum (Brid.) B.S.G.
Thuidium

440-2300 29 delicatulum (Hedw.) B.S.G.

philibertii Limpr.

10001

recognitum (Hedw.) Lindb.

400-2250 52

$1000-23503$

$450-1030 \quad 16$

HELODIACEAE

Helodium

blandozeri (Web. et Mohr) Warnst. $\quad 370-10005$

Palustriella

commutata (Hedw.) Ochyra

$350-2800 \quad 37$

$440-2100 \quad 17$

440-1900 6

decipiens (De Not.) Ochyra

440-2150 17

18501

CratoneuraceaE

Cratoneuron

filicinum (Hedw.) Spruce

$400-2700 \quad 45$

440-2908 49

AmblystegiaCEAE

Amblystegium

serpens.(Hedw.) B.S.G

280-2400 38

- var. juratzkanum (Schimp.) Rau et Herv. 400-450 2 varium (Hedw.) Lindb.

6201

280-450 8

$340-1950 \quad 34$

Callialaria

curoicaulis (Jur.) Ochyra

24501

Calliergon

cordifolium (Hedw.) Kindb.

giganteum (Schimp.) Kindb.

480-1950 5

richardsonii (Mitt.) Kindb.

1220-1980 7

10003

Calliergonella

cuspidata (Hedw.) Loeske

lindbergii (Mitt.) .Hedenaes

(= Hypnum lindbergii)

$500-2300 \quad 17$

Campylium

calcareum Crundw. et Nyh.

chrysophyllum (Brid.) J.Lange

halleri (Hedw.) Lindb.

hispidulum (Brid.) Mitt.

longicuspis (Lindb. et H.Arnell)

Hedenaes

$1700-2300 \quad 4$

440-1000 7

440-2400 25

2300-2400 2

350-620 4

$1700-2100 \quad 4$

4701

280-1000 9

$340-2750 \quad 69$

2100-2400 2

1800-2500 3

2050-2700 2

850-2400 20

410-2750 17

protensum (Brid.) Kindb.

sommerfelti (Myr.) J.Lange

$2550 \quad 1$

1750-2500 3

450-10007

stellatum (Hedw.) C.Jens.

440-2500 19

Conardia

compacta (C.Muell.) Robins.

1220-1800 2

Drepanocladus

aduncus (Hedw.) Warnst.

$1600-2700 \quad 12$

sendtneri (Schimp. ex C.Muell.)Warnst. $1800-26006$

Hamatocaulis vermicosus (Mitt.) Hedenaes

$1950-24003$

Hygrohypnum

440-1850 36

450-800 6

$340-1100 \quad 30$

alpestre (Hedw.) Loeske

2050-2300 4

cochlearifolium (Vent. ex De Not.) Broth. 1900-2800 4

duriusculum (De Not.) Jamieson $\quad 400-240011$

luridum (Hedw.) Jenn. ' 340-2650 23

ochraceum (Turn. ex Wils.) Loeske $\quad 450-21507$

polare (Lindb.) Loeske

$1600-2450 \div 10$

440-2800 $22 \quad$ Leptodictyum

4501 . riparium (Hedw.) Warnst.

Limprichtia

cossonii (Schimp.) Anderson et al

450-530 $3 \quad$ reoolvens (Sw.) Loeske

450-800 6 . Loeskypnum

badium (Hartm.) Paul

$1000-17503$

1700-2800 17

1600-2700 33

$1760-2900 \quad 13$

400-1000 9

4501
Pseudocalliergon

trifarium (Web. et Mohr) Loeske

turgescens (T.Jens.) Loeske
1760-2400 6

2300-2550 7 
Sanionia

uncinata (Hedw.) Loeske

Sarmentypnum

sarmentosum (Wahlenb.)Tuom. et T.Kop. 1300-2900 26

Scorpidium

scorpioides (Hedw.) Limpr.

Serpoleskea

subtilis (Hedw.) Hampe

Stramigeron

stramineum (Brid.) Hedenaes

(= Calliergon stramineum)

Warnstorfia

exannulata (Guemb. in B.S.G.)Loeske

fluitans (Hedw.) Loeske

pseudostraminea (C.Muell.)Tuom. et T.Kop.2250-23002

\section{BRACHYTHECIACEAE}

Brachythecium

albicans (Hedw.) B.S.G.

buchananii (Hook.) Jaeg.

collinum (Schleich. ex C.Muell.) B.S.G.

doorense (Limpr.) Schljak.

erythrorthizon B.S.G.

kuroishicum Besch.

latifolium Kindb.

mildeanum (Schimp.)

Schimp. ex Milde

oedipodium (Mitt.) Jaeg.

plumosum (Hedw.) B.S.G.

populeum (Hedw.) B.S.G.

reflexum (Starke) B.S.G.

rioulare B.S.G.

rutabulum (Hedw.) B.S.G.

salebrosum (Web. et Mohr) B.S.G

starkei (Brid.) B.S.G.

turgidum (Hartm.) Kindb.

velutinum (Hedw.) B.S.G.

zerichurae (Broth.) Par.

Bryhnia

novae-angliae (Sull. et Lesq.) Grout

Cirriphyllum

cirrosum (Schwaegr. in Schultes) Grout

piliferum (Hedw.) Grout

Eurhynchium

angustirete (Broth.) T.Kop

hians (Hedw.) Sande Lac.

pulchellum (Hedw.) Jenn.

- var. praecox (Hedw.) Dix.

sp. $n$.

Homalothecium

philippeanum (Spruce) B.S.G.

Myuroclada

maximoviczii (Borszcz.) Steere et Schof.

Rhynchostegium

riparioides (Hedw.) C.Jens.

Scleropodium

omellanum (Mol.) Lor.

Tomentypnum

nitens (Hedw.) Loeske

10001

$330-100032$

2200-2850 4 20501

$1700-2600 \quad 19$

350-1000 19 23001

440-2850 26

450-2050 12

$350-2100 \quad 18$

$350-2400 \quad 35$

440-1900 9

$280-2150 \quad 27$

450-1000 2

400-2300 31

500-2050 15

$1760-300020$

$450-2700 \quad 50$

330-700 11

2801

$340-2750 \quad 39$

280-1500 12

$280-800 \quad 10$

400-600 5

450-2700 28

2900-2900 3

280-900 14

4401

$280-2000 \quad 30$

$400-470 \quad 10$

850-2050 7

$1000-2800 \quad 23$

ENTODONTACEAE

Entodon

cladorrhizans (Hedw.) C.Muell. (incl. E. scleicheri)
$400-3150 \quad 67$

$1850-2104 \quad 3$

$600-880 \quad 4$

520-2700 59

450-2300 5

compressus (Hedw.) C.Muell

concinnus (De Not.) Par.

280-470 11

$350-2750 \quad 26$

Plagiotheciaceae

Plagiothecium

cavifolium (Brid.) Iwats.

denticulatum (Hedw.) B.S.G.

laetum B.S.G.

latebricola B.S.G.

440-2400 29

440-2850 24

$440-2250 \cdot 24$

4702

SEMATOPHYLlaCEAE

Heterophyllium

affine (Hook. ex Kunth) Fleisch.

$450-8508$

HYPNACEAE

Breidleria

pratense (Koch ex Spruce) Loeske (= Hypnum pratense)

4001

Callicladium

haldanianum (Grev.) Crum

Ctenidium

procerrimum (Mol.) Lindb.

Eurohypnum

leptothallum (C.Muell.) Ando

Gollania

turgens (C.Muell.) Ando

Herzogiella

turfacea (Lindb.) Iwats.

Homomallium

incuroatum (Brid.) Loeske

Hypnum

bambergeri Schimp.

callichroum Funck ex Brid.

cupressiforme Hedw.

- var. subjulaceum Mol.

fertile Sendtn.

hamulosum B.S.G.

pallescens (Hedw.) P.Beauv.

plicatulum (Lindb.) Jaeg.

recuroatum (Lindb. et H.Arnell) Kindb.

revolutum (Mitt.) Lindb.

vaucheri Lesq.

Isopterygiopsis

alpicola (Lindb. et H.Arnell)

Hedenaes

muelleriana (Schimp.) Iwats.

pulchella (Hedw.) Iwats.

Orthothecium

chryseon (Schwaegr. ex Schultes) B.S.G.

intricatum (C.Hartm.) B.S.G.

strictum Lor.

Platydictya

jungermannioides (Brid.) Crum

Platygyrium

repens (Brid.) B.S.G.

Podperaea

krylowi (Podp.) Iwats. et Glime

Ptilium

crista-castrensis (Hedw.) De Not.

Pylaisiella

cf. intricata (Hedw.) Grout

polyantha (Hedw.) Grout

selweynii (Kindb.) Crum et al.

$450-7009$

$2350-26007$

280-950 31

10001

440-700 2

400-1100 19

$1900-28005$

440-2150 6

400-2908 88

560-2150 8

440-1950 10

440-2850 20

400-1950 19

440-2100 4

$1000-1900 \quad 4$

2000-2750 9

$350-250033$

1900-2300 2

450-2180 15

$450-2800 \quad 47$

470-2800 21

440-1950 3

$1800-28008$

$1220-27509$

$360-1200 \quad 17$

450-530 6

440-2240 15

400-1600 2

280-1940 30

400-600 14

Struckia

argentata C.Muell

280-1500 $24 \quad$ - ssp. zerovii (Lazar.) Tan et al. 
Taxiphyllum renssgrilkii (Garov.) Wijk et Marg.

RHYTIDIACEAE

Rhytidium

.rugosum (Hedw.) Kindb.

Hylocomiaceae

Hylocomiastrum

pyrenaicum (Spruce) Fleisch.
$350-1300 \quad 22$

440-2800 22

umbratum (Hedw.) Fleisch.

Hylocomium splendens (Hedw.) B.S.G.

- var. obtusifolium (Geb.) Par.

Pleurozium schreberi (Brid.) Mitt.

Rhytidiadelphus

subpinnatus (Lindb.) T.Kop

600-2600 23 triquetrus (Hedw) Warnst.
470-1030 5

440-2908 16

19501

$450-2908 \quad 16$

400-2050 11

$440-2100 \quad 20$

\section{Literature CITED}

[ABRAMOVA, A. L. \& I. I. ABRAMOV] AБPAMOBA, АЛ. \& И. И. АБРАМОВ 1966. Редкие виды мхов Сибири и Дальнего Востока. - [Rare mosses of Siberia and Far East]. Hoвocmu cucm. Huзu. pacm. [Novosti Sist. Nizsh. Rast.] 1: 302-315.

[ADAMENKO, М. F.] АДАМЕНКО, М. Ф. 1985. Реконстукция динамики термического режима летних месяцев и оледенения на территории Горного Алтая в XIV XX вв. - [Restoration of dynamics of temperature of summer months and glaciation in Altai Mountains in XIV XX centures] Aвтореф..канд. геогр. наук. Новосибирск [Ph. D. Thesis, Novosibirsk], 16.

[BARDUNOV, L. V.] БАРДУНОВ, Л. В. 1974. Листостебельные мхи Алтая и Саян - [Mosses of the Altai and Sayan Mts.]. Hoвocuбupck, Hayкa [Norosibirsk, Nauka], 168.

[BELOV, A. V. \& V. A. BELOVA] БЕЛOB, A. В., В. А. БЕЛОВА 1986. Основные этапы развития растительности Средней Сибири в позднем кайнозое. - [Main stages of development of vegetation of Middle Siberia in Late Cenozoic]. В кн.: История растительного покрова Северной Азии (ред. Л. И. Мальиев) Новосибирск, Наука IIn Malysheo, L. I. (ed.) Istoriya rastitelnogo pokrova Severnoj Azii, Novosibirsk, Nauka]: 42-56.

[BOGACHKIN, В. М.] БОГАЧКИН, Б. М. 1981. История тектонического развития Горного Алтая В кайнозое. [History of tectonic development of Altai Mountains in Cenozoic]. M., Hayкa [Moscow, Nauka], 132

[BOYARSKAYA, Т. D.] БОЯРСКАЯ, Т. Д. 1978. К вопросу о растительности Горного Алтая в позднем плиоцене и плейстоцене. - [On the vegetation of Altai Mountains in Late Pliocene and Pleistocene]. $B$ кн:: Разрез новейuих отложений Алтая (ред. Марков, К. К.) М., Изд. Моск. yн-ma [In: Markov, K. K. (ed.) Razrez novejshikh otlozhenij Altaya. Moscoxe, Izd. Mosk. Unio.j: 173-176.

[BROTHERUS, V. F.] БPOTEPYC, В. Ф. 1914. Мхи (Andreaeales; Bryales часть 1). - [Mosses (Andreaeales, Bryales part 1)]. B кж: Федиенко, Б. A. Флора Азиатской России, Вып. 4. Петроград, Переселениеское управление... In Fedtschenko, B. A. Flora Aziatskoj Rossii, Pt. 4, Petrograd, Pereselencheskoye Upraolenie...]: 1-78.

[BROTHERUS, V. F.] БPOTEPYC, В. Ф. 1918. Мхи
(Bryales часть 2). - [Mosses (Bryales part 2)]. - $B$ кн: Федиеніко, Б. A. Флора Азиатской России, Bыn. 13. Петроград, Нзд. быви. Переселениеского управления... [In Fedtschenko, B. A. Flora Aziatskoj Rossii, Pt. 13, Petrograd]: 1-182.

[BROTHERUS, V. F.] БРОTEPYC, В. Ф. 1931. Мхи Азиатской России (Bryales), часть 3. - [Mosses of Asian Russia (Bryales), part 3]. Tpydu бom. caдa AH CCCP. [Trude Bot. sada Akad. Nauk SSSR] 42(2): 141-180.

CHANG, H. S. 1983. The Tibetan Plateau in Relation to the Vegetation of China. - Ann. Missouri Bot. Gard. 70(3): 564-570.

CZERNYADJEVA, I. V. \& M. S. IGNATOV 1991. Pohlia andrewsii J. Shaw in the U. S. S. R. - J. Bryol. 16(4): 581587.

[GUDOSHNIKOV, V. F.] ГУДОШНИКОВ, С. В. 1986. Флора листостебельных мхов черневого подпояса Южных гор Сибири и проблема происхождения черневой тайги. - [Moss flora of czernevaya subzone of the southern mountains of Siberia and the origin of czernevaya taiga]. Томск, Hзд. Томск. ун-ma [Tomsk, lzd. Tomsk. Univ.], 190.

IGNATOV, M. S. 1990. New recored of mosses from the nortbwestern Altai Mountains. - Acta Bryolichenologica Asiatica 2(1-2): 17-24.

IGNATOV, M. S. 1992. On the occurence of Barbula inaequalifolia Tayl. (Pottiaceae, Musci) in Altai Mountains. -

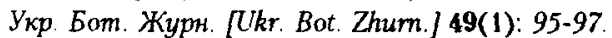

IGNATOV, M. S. 1992. The relationships of moss flora of Altaj Mts. - Bryobrothera 1: 63-72.

IGNATOV, M. S. 1993. Moss diversity patterns on the territory of the former USSR. - Arctoa 2: 13-47.

[IGNATOV, M. S. \& O. M. AFONINA (eds.)] ИГНАТOB, М.С., О.М.АФОНИНА (ред.) 1992. Стисок мхов территории бывшего CCCP. - [Check-list of mosses of the former USSR]. Arctoa 1: 1-85.

IGNATOV, M. S. \& N. B. KURBATOVA 1990. Deep-water bryophytes: a review with new records from the USSR. Hikobia 10: 1-16.

IGNATOV, M. S. \& B. C. TAN 1991. Orthodontopsis, a new genus of Bryaceae (Musci) from southern Siberia, USSR. - $J$. Hattori Bot. Lab. 71: 165-173. 
IGNATOV, M. S. \& R. H. ZANDER 1993. Barbula amplexifolia from the Altai mountains of Russia. - Bryologist 96(4): 638-639

[KELLER, В. А] КЕЛЛЕР, Б. А. 1914. По долинам и горам Алтая. - [Though valleys and mountains of Altai]. Tpydu почв.-бот. экспедиций по исслед. колонизационных районов Азиатской России. Ч. 2. Бот. исслеd. 1910 а. [Trudy Poczv-Bot. Expedizij po Issled. Kolonizazionnykh rajonov Aziatskoi Rossii. Pt. 2. Bot. Issled. 1910 goda] 6: 1-444.

[KHOMUTOVA, M. S., M. V. ZOLOTOVSKIJ \& A. N. GONCHAROVA] 1938. ХOМУTOBA, M.C., М.В.ЗОЛОТОВСКИЙ, А. Н. ГОНЧАРОВА. 1938. Список растений Алтайского государственого заповедника. - [List of plants of Altaian State Reserve]. Tpydu Almaŭcкого заповедника [Trudy Altaiskogo Zapovednika] 2: 139-247.

[KLIMANOV, V. А.] КЛИМАНОВ, В. А. 1989. Палеоклиматические реконструкиии на территории СССР в главный термический максимум голоцена (по палинологическим данным). - [Paleoclimatic restorations on the territory of the USSR in the main climatic maximum of Holocene (according palinological data)] Труды Ин-та Геол. и Геофиз. CO АH CCCP [Trudy Inst. Geol. Geophys. Sib. Otd. Akad. Nauk SSSR] 657: 137-145

[KRIVONOSOV, В. М.] КРИВOНOCOB, Б. М. 1975. Климаты Горного Алтая. - [Climates of the Altai Mountains]. Автореф. ...канд. биол. наук, Томск [Ph. D. Thesis, Tomsk ], 24.

[KRYLOV, A. G. \& S. P. RECHAN] KРЫЛOB, А. Г., С. П. PЕЧАН 1967. Типы кедровых и лиственничных лесов Горного Алтая. - [Types of Pinus sibirica and Larix sibirica forests in Altai Mountains]. M., Hayкa [M., Nauka], 215

[KRYLOV, P.] КРЫЛОВ, П. 1925. Материалы к флоре споровых растений Алтая и Томской губернии. - [Contributions to the flora of spore plants of Altai and Tomsk Province]. Изе. Томск. Гос. YH-ma [Izz. Tomsk. Gos. Univ.] 75: $1-48$

[KULIK, T. G.] КУЛИК, Т. Г. 1990. Материалы по семействам Brachytheciaceae (роды Isothecium, Myuroclada, Scleropodium), Entodontaceae (род Entodon), Hурnaceae (род Pleurozium) в бриологическом гербарии. - [Sресіmens of families Brachytheciaceae (genera Isothecium, Myuroclada, Scleropodium), Entodontaceae (genus Entodon), Hypnaceae (genus Pleurozium) in bryological herbarium]. Каталог музейньх фондов (ред. Климинин, A. C.), Львов, АН УССР, Гос. Природоведиеский Музей YCCP [In: Klimishin, A. S. (ed.) Katalog muzeinykh fondov. Loov, Akad. Nauk Ukr. SSR, Gos. Prirodovedcheskij Musei]. $6 \cdot 25$.

[KULIK, T. G. \& K. O. ULYCHNA] КУЛИК, Т. Г., К. О УЛЫЧНА 1990. Бриологический гербарий. Семейство Neckeraceae. - [Bryological Herbarium. Family
Neckeraceae]. Каталог музейнъих фондов (ред. Климапииюs, А. С.), Лввов, АН УССР, Гос. Природоведиеский Музей YCCP [In: Klimishin, A. S. (ed.) Katalog muzeinykh fondov. Loov, Akad. Nauk Ukr. SSR, Gos. Prirodovedcheskij Musei]: $26-44$

[KUMINOVA, A. V.] КУМИНОВА, А. В. 1960. Растительный покров Алтая. - [Vegetation of the Altai]. Hoвосибирск, Hayкa [Novosibirsk, Nauka], 450.

[LAZARENKO, A. S.] ЛАЗАРЕНКО А. С. 1946. Бріологічні нотатки - [Bryological notes]. Бот. журн. АH УPCP [Bot. Zhum. Akad. Nuuk UkrRSR](1946)(3-4): 61-63.

[MALYSHEV, L. I. \& G. A. PESHKOVA] MAЛЫШEB, Л. И., Г. А. ПЕШКОВА 1984 Особенности и генезис флоры Сибири (Предбайкалье и Забайкалье). - [Pеculiarities and genesis of flora of Siberia (Cis- and Transbaikal Region)] Новосибирск, Hayкa [Novosibirsk, Nauka], 265.

[OGUREEVA, G. N.] OГУPEEBA, Г. Н. 1980. Ботаническая география Алтая. - [Phytogeography of the Altai]. M., Hayкa [Moscow, Nauka], 189.

[OKISHEV, Р. А.] ОКИШЕВ, П. А. 1982. Динамика оледенения Алтая в позднем плейстоцене и голоцене. [Dinamics of the glaciation of Altai in Late Pleistocene and Holocene]. Томск, Изд-во Томск. $Y_{H-m a}$ [Tomisk, Izd. Tomsk. Unio.J, 210.

[SEMENOV, В. S.] СЕMEНОВ, Б. С. 1922 Листостебельные мхи Западной Сибири, Ч. I-II. [Mosses of Western Siberia, Pt. 1 \& 2]. Tpydu 3an.-Сиб. Отд. РГО (Омск) [Trudy Zap.-Sib. Otd. Ross. Geogr. Obshch. (Omsk)] 2: 158.

[SEMENOV, B. S.] CEMEHOB, Б. C. 1921 Сфагны Алтая. - [Sphagna of Altai]. Tpyдz Aлmaŭck noдomдеra PTO (Барrays) [Trudy Altaisk. podotdela Ross. Geogr. Obshch. (Bamaul)] 1: 1-44.

TAN, B. C., W. R. BUCK \& M. S. IGNATOV 1990. On the Himalayan Struckia C. Muell. and Russian Cephalocaldium Lazar. (Musci, Hypnaceae). - Lindbengia 16(3): 100104.

[ULYCHNA, К. О.] УЛЫЧНА, К. О. 1990. Бриологический гербарий. Семейства Ptychomitriaceae, Cryphaeaceae, Hypopterygiaceae и Fabroniaceae. - [Bryological Herbarium. Families Ptychomitriaceae, Cryphaeaceae, Hypopterygiaceae and Fabroniaceae]. Kamaroz мyзеíных фондов (ред. Климаишин, А. С.), Льеов, АН УССР, Гос. Природоведческий Музей уСCP [In: Klimishin, A. S. (ed.) Katalog muzeinykh fondov. Loov, Akad. Nauk Ukr. SSR, Gos. Prirodovedcheskij Musei]: 45-49.

[ZASS, A.] 3АСC, А. 1894. Список растений, собранных в Aлтайском округе с 1875 по 1893 r. - [List of plants collected in Altaiskij Province in 1875-1893]. Aлmaùcкuй сборник [Altaiskij sbormik] 1: 1-45. 